\title{
Efficacy of clinoptilolite supplementation on milk yield and somatic cell count
}

\author{
La eficacia de la suplementación con clinoptilolita sobre la \\ producción de leche y el recuento de células somáticas
}

\begin{abstract}
Deniz Alic Ural, Ph.D.
Adnan Menderes University, Bozdogan Vocational School, Campus of Rasim Mentese, 09760, Bozdogan, Aydın, Turquía. Corresponding: alicdeniz@gmail.com.
\end{abstract}

Received: November 2013; Accepted: March 2014.

\begin{abstract}
Objective. To determine the efficiency of clinoptilolite supplements on milk production and somatic cell count (SCC). Materials and methods. 80 Holstein-Friesian cows were used, between 2 and 4 years of age ad between their first and third lactation. Two groups made up of 40 animals were constituted, and one of the following treatments were assigned randomly: Control group $(n=40)$ with a basal diet, and experimental group (Clinoptilolite; $n=40$ ) with a basal diet $+3 \%(p / p)$ of clinoptilolite. The basal diet consisted of corn, hay, sunflower flour, barley grains, wheat bran and soy flour. The experiment lasted 16 weeks (February to June 2013) and began 4 weeks before the expected delivery date. 2560 milk samples were taken (morning and evening), and the farm was visited twice a week. Results. The mean values for the control group and the clinoptilolite group were $30.63 \pm 0.851$ and $33.66 \pm 0.756$, respectively. Milk prouction for the clinoptilolite group was higher than that of the control group $(p<0.01)$. SCC for the control and clinoptilolite groups was $5.06 \pm 0.045$ and $4.79 \pm 0.011$, respectively $(p<0.01)$. Conclusions. Supplementing with $3 \%(p / p)$ clinoptilolite in dairy cows increases milk production and decreases somatic cell count.
\end{abstract}

Key words: Diet, feeding, milk yield, zeolita (Fuente: $C A B$ ).

\section{RESUMEN}

Objetivo. Determinar la eficacia de la suplementación con clinoptilolita sobre la producción de leche y recuento de células somáticas (RCS). Materiales y métodos. Se utilizaron 80 vacas Holstein-Friesian, entre 2 y 4 años de edad y entre la primera y tercera lactancia. Se conformaron dos grupos de 40 animales y al azar se les asignó uno de los siguientes tratamientos: Grupo control $(n=40)$ con dieta basal y un grupo experimental (Clinoptilolita; $n=40$ ) con dieta basal $+3 \%(p / p)$ de clinoptilolita. La dieta basal consistió de maíz, heno, harina de girasol, granos de cebada, salvado de trigo y harina de soja. El experimento se llevó a cabo en 16 semanas (febrero a junio de 2013) y se inició 4 semanas de la fecha esperada del parto. Se tomaron 2.560 muestras de ordeño de leche (mañana y tarde), las visitas a la granja fueron realizadas dos veces por semana. Resultados. Los valores medios para el grupo control y el grupo clinoptilolita fueron $30.63 \pm 0.851$ y $33.66 \pm 0.756$, respectivamente. La 
producción de leche para el grupo clinoptilolita fue mayor que en el grupo control $(p<0.01)$. El RCS para los grupo control y clinoptilolita fue de $5.06 \pm 0.045$ y $4.79 \pm 0.011$, respectivamente $(p<0.01)$. Conclusiones. La suplementación de $3 \%(\mathrm{p} / \mathrm{p})$ de clinoptilolita en la dieta de vacas lecheras incrementa la producción de leche y disminuye el recuento de células somáticas.

Palabras clave: Alimentación, dieta, rendimiento lechero, zeolita, (Fuente: $C A B$ ).

\section{INTRODUCTION}

The quality of milk yield possess importance in the dairy industry and milk quality as milk yield of dairy cattle is majorly impressed by diet (1). Recently, the natural zeolite, clinoptilolite has a widespread area of usage as feed additive in dairy rations (1-3). Clinoptilolite is a crystalline hydrated alluminosilicates (4) including a chemical elements as the vast majority [alkaline $(\mathrm{Na}, \mathrm{K}, \mathrm{Rb}, \mathrm{Cs})$ and earth alkaline ( $\mathrm{Mg}, \mathrm{Ca}, \mathrm{Sr}, \mathrm{Ba}]$ (5-9). Clinoptilolite is very substantial because of causing increase in feed efficienciency and milk production on dairy cattle, besides it may reduce mastitis problems (10). There is scarcity and spatially defined information relevant to dietary addition of clinoptilolite on milk yield. Besides, according to the present author's knowledge detailed data is lacking for the efficacy of clinoptilolite on SCC.

The present author's interest to this subject was aroused following the evaluation and interpretation of a prior original research, involving clinoptilolite supplementation to diet for increasing milk yield (11). According to the positive results of the latter study, the increasing demands of the dairy farmers request for dietary improvement for milk yield and given the results of prior researches evaluating the effect of different levels of supplemental zeolite, it was hypothesized that clinoptilolite would be effective for improving milk yield. Thus, the purpose of the present study was to asses the efficacy of dietary clinoptilolite addition on milk yield and besides somatic cell count.

\section{MATERIAL AND METHODS}

Site of the study and animals. This study was carried out using clinically healthy 80 head Holstein-Friesian cows between $1^{\text {st }}$ and $3^{\text {rd }}$ lactation, 2-4 years old in a private dairy farm in Aydin province, Turkey. The animals were enrolled into two groups.

Assigment of treatments. Group 1: Control Group comprised of 40 cows. They were fed basal diet (Table 1).

\section{INTRODUCCIÓN}

La calidad de la producción de leche posee importancia en la industria láctea, ya que la producción de leche del Ganado lechero se ve influenciada en su mayor parte por la dieta (1). Recientemente, la clinoptilolita, una zeolita natural, ha tenido un amplio campo de uso como aditivo alimenticio en las raciones de alimento (1-3). La clinoptilolita es un aluminosilicato cristalino hidratado (4) incluyendo elementos químicos como la vasta mayoría [alcalinos ( $\mathrm{Na}$, $\mathrm{K}, \mathrm{Rb}, \mathrm{Cs})$ y alcalinotérreos $(\mathrm{Mg}, \mathrm{Ca}, \mathrm{Sr}, \mathrm{Ba}](5-9)$. La clinoptilolta es muy sustancial porque causa un incremento en la eficiencia de la dieta y la producción láctea del ganado lechero, además de que puede disminuir los prolemas de (10). La información acerca de la suplementación dietaria de clinoptilolta sobre la producción lechera es escasa y dispersa. Además, de acuerdo con el conocimiento actual del autor, hacen falta datos detallados acerca de la eficacia de la clinoptilolita sobre el RCS.

El interés del presente autor sobre este tema surgió luego de la evaluación e interpretación de una investigación original previa, que incluía la suplementación dietaria con clinoptilolita para incrementar la producción lechera (11). De acuerdo con los resultados positivos del estudio posterior, las crecientes necesidades de los granjeros lecheros require de un mejoramiento de la dieta para la producción lechera, y dados los resultados de las investigaciones previas al evaluar los efectos de diferentes niveles de zeolita suplementaria, surgió la hipótesis de que la clinoptilolita podría ser efectiva para mejorar la producción lechera. En consecuencia, el objetivo del presente estudio fue evaluar la eficacia de la adición de clinoptilolita en la dieta sobre la producción lechera, y de paso, sobre el recuento de células somáticas.

\section{MATERIALES Y MÉTODOS}

Lugar de estudio de los animales. Este estudio se llevó a cabo usando 80 vacas HolsteinFresian clínicamente sanas, entre 2 y 4 años de edad y entre la primera y tercera lactancia, en 
Table 1. Ingredient composition of basal diet.

\begin{tabular}{lc}
\hline \multicolumn{1}{c}{ Ingredient } & \%DM \\
\hline Corn silage (35\% v/v DM) & 48.39 \\
Hay & 18.20 \\
Sunflower meal (44\% v/v CP) & 8.0 \\
Barley grains & 8.0 \\
Wheat bran & 6.25 \\
Soybean meal (25\% v/v CP) & 4.45 \\
Vitamin and mineral premix & 1.88 \\
Calcium carbonate & 1.75 \\
Sodium bicarbonate & 1.68 \\
Dicalcium phosphate & 1.02 \\
Salt & 0.38 \\
\hline
\end{tabular}

Crude protein of basal diet (Dry Matter(DM) \%): $15.40 ; \mathrm{NE}_{1}$ (Net energy lactation) (Mcal/kg DM): 1.46; Contained in $\mathrm{kg}$ of mineral-vitamin premix: Vitamin A 90.000 UI; Vitamin D 6000 UI; Vitamin E 60 mg; Vitamin PP 900 mg; Vitamin B1 7.50 mg; Vitamin B2 7.50 mg; Zinc $240 \mathrm{mg} \mathrm{kg}^{-1}$; Iron $150 \mathrm{mg} \mathrm{kg}^{-1}$; Selenium $1 \mathrm{mg} \mathrm{kg}^{-1}$; Iodium $3 \mathrm{mg} \mathrm{kg}^{-1}$

Group 2: Clinoptilolit group involved 40 cows. They were fed basal diet $+3 \%$ clinoptilolite.

Clinoptilolite material. Natural Clinoptilolite was assured from Gordes Zeolit Mining, Izmir, Turkey. The $\mathrm{NH}_{4}$ ion exchange capacity of clinoptilolite material was $1.7-2.1 \mathrm{meq} / \mathrm{g}$ and its chemical composition is $\mathrm{SiO}_{2} 67.11 \%(\mathrm{w} / \mathrm{v})$, $\mathrm{Al}_{2} \mathrm{O}_{3} 11.84 \%$ (w/v), $\mathrm{Fe}_{2} \mathrm{O}_{3} 1.47 \%(\mathrm{w} / \mathrm{v}), \mathrm{MgO}$ $1.15 \%(\mathrm{w} / \mathrm{v}), \mathrm{CaO} 2.18 \%(\mathrm{w} / \mathrm{v}), \mathrm{Na}_{2} \mathrm{O} 0.38 \%$ $(\mathrm{w} / \mathrm{v}), \mathrm{K}_{2} \mathrm{O} 3.44 \%(\mathrm{w} / \mathrm{v})$ and LOI (Loss on ignition) $12.5 \%$.

Experimental design. The experiment was carried out for 16 weeks, from 2013 February to 2013 June. The experiment was started 4 weeks before expected day of parturition. Each cow in control and clinoptilolite groups were fed $30 \mathrm{~kg}$ corn silage, $3 \mathrm{~kg}$ molasses and $3 \mathrm{~kg}$ concentrates per day until parturition. Through lactation each cow received $35 \mathrm{~kg}$ corn silage in conjunction with $3 \mathrm{~kg}$ molasses and $400 \mathrm{~g}$ concentrates per liter of milk production. The feeding was twice a day 09:00 and 16:00 in barn. The ingredients composition of basal diet was shown in table 1 .

Somatic cell count (SCC) analysis. Farm was visited biweekly and approximately about 2560 milk samples (morning and evening milking samples) were collected. The milk samples from each cow were withdrawn from each teat into tubes among both the morning and evening milking. Morning milking was stored in a cooler box and then was immediately transferred to the laboratory and milk samples were analyzed within the same day. Evening milk samples were kept in a refrigerator and analyzed the next day immediately. All samples were treated according to the directions given previously (12) and Standard Methods for the Examination of una granja lechera privada en la provincial de Aydin, Turquía. Los animales se separaron en dos grupos.

Asignación de los tratamientos. Grupo 1: Grupo control compuesto por 40 vacas. Se alimentó con dieta basal (Tabla 1).

Grupo 2: Grupo experimental compuesto por 40 vacas. Se les alimentó con dieta basal $+3 \%$ de clinoptilolita.

Material de clinoptilolita. Se adquirió clinoptilolita natural de Gordes Zeolit Mining, Izmir, Turquía. La capacidad de intercambio de iones $\mathrm{NH}_{4}$ del material de clinoptilolita fue de $1.7-2.1 \mathrm{meq} / \mathrm{g}$ y sucomposición química es $\mathrm{SiO}_{2} 67.11 \%(\mathrm{w} / \mathrm{v}), \mathrm{Al}_{2} \mathrm{O}_{3} 11.84 \%(\mathrm{w} / \mathrm{v}), \mathrm{Fe}_{2} \mathrm{O}_{3}$ $1.47 \%(\mathrm{w} / \mathrm{v}), \mathrm{MgO} 1.15 \%(\mathrm{w} / \mathrm{v}), \mathrm{CaO} 2.18 \%$ $(\mathrm{w} / \mathrm{v}), \mathrm{Na}_{2} \mathrm{O} 0.38 \%(\mathrm{w} / \mathrm{v}), \mathrm{K}_{2} \mathrm{O} 3.44 \%(\mathrm{w} / \mathrm{v})$ y LOI (Pérdida por Ignición, por sus siglas en inglés) $12.5 \%$.

Diseño experimental. El experimento se llevó a cabo durante 16 semanas, entre febrero y junio de 2013. Se dio comienzo al experimento 4 semanas antes dela fecha esperada de parto. Cada vaca de los grupos de control y de clinoptilolita recibió $30 \mathrm{~kg}$ de ensilado de maíz, $3 \mathrm{~kg}$ de melaza y $3 \mathrm{~kg}$ de concentrado al día, hasta el parto. Durante la lactancia, cada vaca recibió $36 \mathrm{~kg}$ de ensilado de maíz junto con $3 \mathrm{~kg}$ de melaza y $400 \mathrm{~g}$ de concentrados por litro de leche producida. La alimentación se hizo dos veces al día, a las 09:00 y a las 16:00 en un establo. La composición de la dieta basal se muestra en la tabla 1.

Análisis del recuento de células somáticas (RCS). Se hicieron visitas a la granja dos veces por semana y se tomaron aproximadamente 2560 muestras de leche (ordeños de mañana y tarde). Las muestras fueron tomadas de cada teta por tubos tanto en el ordeño de la mañana como en el de la tarde. El ordeño de la mañana fue almacenado en un una caja refrigerada y transferido inmediatamente al laboratorio, y se examinaron el mismo día. Las muestras del ordeño de la tarde se guardaron en un refrigerador y se analizaron al día siguiente. Todas las muestras fueron tratadas de conformidad con las indicaciones previamente dadas (12) y con los Métodos Estándar para el Examen de Productos Lácteos (13). El RCS de las muestras se determinó por medio del método microscópico directo de RCS (14). Las muestras de leche se esparcieron sobre dos áreas del portaobjetos de microscopio, con un tamaño de $5 \times 20 \mathrm{~mm}^{2}$. Las láminas se prepararon de acuerdo con el Recuento Directo de Células Somáticas, y almacenadas a $37^{\circ} \mathrm{C}$ en una incubadora. 
Dairy Products (13). SCC in the samples was determined by direct microscopic SCC method (14). Milk samples were spread on 2 microscope slide areas, within $5 \times 20 \mathrm{~mm}^{2}$ in size. Slides were prepared according to Direct Microscopic Somatic Cell Count and were kept at $37^{\circ} \mathrm{C}$ in an incubator. Then, milk samples on slides were stained by use of methylene blue. The dye solution was prepared comprising $0.6 \mathrm{~g}$ of certified methylene blue chloride to $54 \mathrm{~mL}$ of $96 \%(\mathrm{v} / \mathrm{v})$ ethyl alcohol, $40 \mathrm{~mL}$ of tolien and $6 \mathrm{~mL}$ glacial acetic acid. The counting was fulfilled in 20 fields under a 100x immersion objective in each slide, followed by average calculation. The multiplication of the microscope factor with the latter average values was corresponded to SCC in per $\mathrm{mL}$ of milk.

Statistical analysis. Statistical analysis was performed by use SPSS 17.0 for Windows (15). The repeated measures analysis approach was analyzed by using ANOVA procedure with mixed linear models was used for statistical analysis of data. The significance of the differences between groups was compared by Duncan's multiple range test (16).

\section{RESULTS}

The results relevant to SCC and milk production were shown in table 2 .

Table 2. The effects of clinoptilolite on somatic cell count and milk production.

\begin{tabular}{lccc}
\hline & $\begin{array}{c}\text { Control Group } \\
\bar{X} \pm S_{\bar{X}}\end{array}$ & $\begin{array}{c}\text { Clinoptilolite } \\
\text { Group } \\
\bar{X} \pm S_{\bar{X}}\end{array}$ & $\begin{array}{c}\text { Statistical } \\
\text { significance }\end{array}$ \\
\hline No.of cows & 40 & 40 & \\
Daily Milk production & $30.63 \pm 0.851^{\mathrm{a}}$ & $33.66 \pm 0.756^{\mathrm{b}}$ & $* *$ \\
SCC (log SCC) & $5.06 \pm 0.045^{\mathrm{a}}$ & $4.79 \pm 0.011^{\mathrm{b}}$ & $* *$ \\
Re-transformation SCC & 115.456 & 62.245 & \\
\hline
\end{tabular}

$* *=p<0.01 ; a, b=$ Means with different superscripts in each line are different

The mean values of control and clinoptilolite group for daily milk production were found as $30.63 \pm 0.851$ and $33.66 \pm 0.756$, respectively. The daily milk production in clinoptilolite group was higher than control group. The difference between groups in milk yield was found statistically significant $(p<0.01)$.

\section{DISCUSSION}

The overall means of control and clinoptilolite group for SCC were found as 5.06 \pm 0.045 and
Posteriormente se tiñeron las muestras de leche con azul de metileno. La solución de tinción se preparó con $0.6 \mathrm{~g}$ de azul de metileno cloruro en $54 \mathrm{~mL}$ de alcohol etílico al $96 \% \mathrm{v} / \mathrm{v}, 40 \mathrm{~mL}$ de tolien/tolueno, y $6 \mathrm{ml}$ de ácido acético glacial. El conteo se hizo en 20 campos bajo un objetivo de inmersión de 100x en cada lámina, seguido de un cálculo de promedios. La multiplicación del factor del microscopio por los valores promedio correspondió al RCS por $\mathrm{mL}$ de leche.

Análisis estadístico. El análisis estadístico se llevó a cabo con el uso de SPSS 17.0 para Windows (15). El enfoque de análisis de medidas repetitivas se analizó por medio del procedimiento ANOVA con modelos lineales mixtos para el análisis estadístico de los datos. La significancia de las diferencias entre grupos se comparó por medio del test de rango múltiple de Duncan (16).

\section{RESULTADOS}

Los resultados relevantes para el RCS y la producción de leche se muestran en la tabla 2.

Se halló que los valores medios para la producción diaria de leche para los grupos de control y de clinoptilolita fueron $30.63 \pm 0.851$ y $33.66 \pm 0.756$, respectivamente. La producción diaria de leche en el grupo de clinoptilolita fue mayor que la del grupo de control. La diferencia entre la producción de cada grupo es estadísticamente significativa $(p<0.01)$.

\section{DISCUSIÓN}

Se halló que los promedios para los grupos de control y de clinoptilolita para el RCS fueron $5.06 \pm 0.045$ y $4.79 \pm 0.011$, respectivamente. El RCS en el grupo de control fue menor que en el de clinoptilolita. Se halló que la diferencia del RCS entre grupos es estadísticamente significativa $(p<0.01)$.

Los resultados de estudios previos pueden ser de ayuda para la interpretación de los datos disponibles obtenidos en el presente estudio. Dschaak et al (2) reportaron que no había diferencia entre tres grupos en tratamiento (control, control $+1.4 \%$ bicarbonato sódico, y control $+1.4 \%$ zeolita). De forma similar, la adición de zeolita $6 \%(\mathrm{p} / \mathrm{v})$ a la dieta concentrada de ganado Pardo Suizo no arrojó diferencias significativas en cuanto a la producción lechera (17). En otra prueba en Italia, la adición de $200 \mathrm{~g} /$ día de clinoptilolita a 32 vacas Holstein lactantes no afectó la producción de leche (5). 
$4.79 \pm 0.011$, respectively. The control group SCC was found lower than clinoptilolite group. The difference between groups for SCC was found statistically significant $(p<0.01)$.

The results of prior studies may help for the interpretation of the available data obtained in the present study. Dschaak et al (2) reported that there was no difference among 3 treatment groups (control, control $+1.4 \%$ sodium bicarbonate and control $+1.4 \%$ zeolite). Similarly, $6 \%(w / v)$ zeolite added to the concentrate diet to the lactating Brown Swiss cattle did not result in significant difference regarding milk yield (17). In another trial in Italy, $200 \mathrm{~g} /$ day clinoptilolite addition to 32 lactating Holstein cows did not affect milk yield (5).

In this study, the effect of clinoptilolite addition on milk production was observed and statistically significant difference was detected between the groups. Similarly, Dyachenko and Lysenko (18) recorded that addition of type $A / B$ zeolite to Russian diet resulted in increased milk production. Furthermore, additive sodium zeolite into corn silage with varying ranges as $0.5 \%(\mathrm{w} / \mathrm{v})(19)$, $2 \%(\mathrm{w} / \mathrm{v})(20)$ and as $4 \%(\mathrm{w} / \mathrm{v})(21)$ caused increased milk yield. Ilić et al (1) described that milk yield was increased by supplementation of $4 \%$ $(\mathrm{w} / \mathrm{v})$ and $2 \%(\mathrm{w} / \mathrm{v})$ zeolite. A novel original study performed by the present author also suggested that $2 \%(\mathrm{w} / \mathrm{v})$ clinoptilolite supplementation for 120 days significantly $(p<0.01)$ affected milk yield (11). The results obtained from the present study and aforementioned researchers suggested that clinoptilolite supplementation may have positive influence on milk yield.

In a prior study in Holstein cows with spontaneous mastitis, the effects of natural mixture involving zeolite powder on the somatic cell count was investigated with 3 different experimental models. Neither experiment I (stevia liquid) nor II (astaxanthin mixed feed), did not have any effect on reducing the linear score or bacteria count of the mastitis cows. However Experiment III revealed that zeolite powder reduced the milk somatic cell count (22). In another trial determining the effect of long-term dietary clinoptilolite supplementation on performance and selected serum biochemical values in dairy goats, concentrated feed along of with $2.5 \%(\mathrm{w} / \mathrm{v})$ clinoptilolite improved milk fat percentage, without adverse effects on the serum variables evaluated. Besides the reduction of SCC achieved with clinoptilolite supplementation suggested improved milk hygiene (23).

In the present study SCC was found significantly lower $(p<0.01)$ in clinoptilolite group $(4.79 \pm 0.011)$ in contrast to the control group (5.06 \pm 0.045$)$. On the contrary, the difference between clinoptilolite
En este estudio, se observe el efecto de la adición de clinoptilolita sobre la producción de leche y se detectó una diferencia estadísticamente significativa entre los grupos. Así mismo, Dyachenko y Lysenko (18) registraron que la adición de zeolite de tipo A/B daba como resultado una producción de leche aumentada. Además, la adición de sodium zeolite/zeolita sódica/zeolita al ensilado de maíz en variedad de rangos tales como $0.5 \%$ ( $p / v)(19), 2 \%$ $(p / v)(20)$ y $4 \%(p / v)$ (21) causaban una producción lechera aumentada. Ilić et al (1) describieron que la producción de leche se incrementaba al suplementar con zeolita al $4 \%$ $(p / v)$ y $2 \%(p / v)$. Un nuevo estudio original llevado a cabo por el presente autor también sugiere que una suplementación de $2 \%(p / v)$ de clinoptilolita durante 120 días, afectaba significativamente $(p<0.01)$ la producción de leche (11). Los resultados obtenidos a partir del presente estudio y de los investigadores mencionados sugirieron que la suplementación con clinoptilolita podría tener una influencia positiva en la producción lechera.

En un estudio anterior sobre vacas Holstein con mastitus espontánea, se investigaron los efectos de la mezcla natural incluyendo polvo de zeolita sobre el recuenrto de células somáticas en tres diferentes modelos experimentales. $\mathrm{Ni}$ el experimento I (estevia líquida) ni el II (astaxantina mezclada en la dieta), tuvieron efecto alguno sobre la reducción del linear score/conteo lineal o del recuento de bacterias de las vacas con mastitis (22). En otra prueba para determinar los efectos a largo plazo de la suplementación de la dieta con clinoptilolita sobre valores séricos bioquímicos específicos en cabras lecheras, la alimentación con concentrado y $2.5 \%(\mathrm{p} / \mathrm{v})$ de clinoptilolita mejoró el porcentaje de grasa, sin efectos adversos sobre las variables séricas evaluadas. Además de la reducción de RCS logrado con la clinoptilolita, la suplementación sugirió una mayor higiene de la leche (23).

En el presente estudio se halló que el RCS fue significativamente inferior $(p<0.01)$ en el grupo de clinoptilolita $(4.79 \pm 0.011)$ en contraste con el grupo de control (5.06 \pm 0.045$)$. Por el contrario, Bosi et al hallaron que la diferencia para el RCS entre el grupo de clinoptilolita y el grupo de control no era significativa.

Tomando en cuenta este estudio experimental, la producción de leche y el recuento de células somáticas se vieron afectados de forma positiva y estadísticamente significativa en las vacas lecheras que recibieron un suplemento de $3 \%(p / v)$ de clinoptilolita. Finalmente, 
and control group was found non-significant for SCC by Bosi et al (5).

Taking regard this experimental study, milk yield and somatic cell count were positive affected statistically significant in dairy cows that was fed clinoptilolite supplementation with $3 \%(\mathrm{w} / \mathrm{v})$. Finally, both elevation of milk yield and reduction of SCC were provided in dairy cow that was fed with $3 \%(w / v)$ clinoptilolite supplementation. Furthermore, other management practices must be applied with at most care accompanying to clinoptilolite supplementation of diets for dairy farms. tanto la elevación de la producción de leche como la reducción del RCS se dieron en las vacas lecheras alimentadas con suplemento de $3 \%(\mathrm{p} / \mathrm{v})$ de clinoptilolita. Adicionalmente, otras prácticas de manejo deben ser aplicadas con el mayor cuidado en el acompañamiento de la suplementación dietaria en las granjas lecheras.

\section{REFERENCES}

1. IIić Z, Petrović MP, Pešev S, Stojković J, Ristano B. Zeolite as a factor in the improvement of some production traits of dairy cattle. Biotech Anim Husb 2011; 27(3):1001-1007.

2. Dschaak CM, Eun JS, Young AJ, Stott RD, Peterson S. Effects of supplementation of natural zeolite on intake, digestion, ruminal fermentation, and lactational performance of dairy cows. Prof Anim Sci 2010; 26:647-654.

3. Karatzia MA, Pourliotis K, Panagiotis DK, Karatzias $\mathrm{H}$. Effects of in-feed inclusion of clinoptilolite on blood serum concentrations of aluminium and inorganic phosphorus and on ruminal $\mathrm{pH}$ and volatile fatty acid concentrations in dairy cows. Biol Trace Elem Res 2011; 142:159-166.

4. Mumpton FA, Fishman PH. The application of natural zeolites in animal science and aquaculture. J Anim Sci 1977; 45:1188-1203.

5. Bosi P, Creston D, Casini L. Production performance of dairy cows after the dietary addition of clinoptilolite. Ital J Anim Sci 2002; 1:187-195.

6. Karadeniz RB. Doğal zeolite (klinoptilolite) atıksulardan amonyak giderimi. [MS Thesis]. Ankara, Turquia: Hacettepe Üniversitesi Fen Bilimleri Enstitüsü; 2003.

7. Rotamin yem katkısı. Rota Madencilik, Rota Mad Hay Tar Nak Dis Tic 2008; (access September 10, 2013) URL available: http:// www.zeoliteproducer.com/rotamintr.html
8. Omid A, Mohamadi A, Nori A, Yarinejad F. The use of zeolite for the reduction of risk of milk fever in dairy cows. Iran International Conference (IIZC'08). CIVILICA: Tehran-Iran; 2008. (access September 10, 2013) URL available in: http://www.civilica.com/PaperZEOLITE01-ZEOLITE01_030.html

9. Erwanto IR, Zakaria WA, Prayuwidayati M. The use of ammoniated zeolite to improve rumen metabolism in ruminant. Anim Prod 2012; 13(3):138-142.

10. ETS zeolite is of great value in the cattle industry in the dollowing ways: beef cattle, dairy cattle, other benefits. ETSZeolite[en liena]. 2013. (Access September 10, 2013) URL available in: http://www.etszeolite.com/html/cattle.html

11. Ural DA, Cengiz O, Ural K. Dietary clinoptilolite addition as a factor for the improvement of milk yield in dairy cows. J Anim Vet Adv 2013; 12(2):140-145.

12. Breed RS. The microscopic appearance of unpasteurized market milk and cream. New York State: Agricultural Experiment Station, Geneva Bull; 1929.

13. Packard VS, Tatini VS, Fugua R, Heady J, Gilman C. Direct microscopic methods for bacteria or somatic cells. $16^{\text {th }}$ ed. Washington, DC: Am Public Health Assoc; 1992.

14. Packard VS, Ginn RE. Standard methods for the examination of dairy products. Am Public Health Assoc 1985; 219-237. 
15. SPSS. Social sciences research and instructional council teaching resourches depository. SPSS for Windows, Version 17.0; 2011.

16. Duncan DB. Multiple range and multiple $F$ test. Biometrics 1995; 11:42.

17. Azman MA, Umucaillar HD, Aral E, Akin AI. Sut ineklerinde verim performansi, rumen parametreleri ve sindirilebilirlik uzerine zeolitin etkisi. Vet Bil Derg 1999; 15:105-109.

18. D'Yachenko LS, Lysenko VF. Natural zeolites in the diets for high-yielding cows. Zootekhniya $1988 ; 128(2): 43-45$.

19. Roussel JD, Adkinson RW, Thibodeaux JK, Toups GM, Goodeaux LL. Effects of feeding sodium zeolite-A on milk yield and composition in thermally stressed Holstein cows. J Dairy Sci 1991; 74(1):300.

20. Garcia Lopez R, Elias A, De La Paz JP, Gonzalez $\mathrm{G}$. The utilization of zeolite by dairy cows. I The effect on milk composition. Cuban J Agric Sci 1988; 22:22-33.
21. Kirilov MP, Fantin VM, Kumarin SV, Kirilova NI, Sadykov S. Zeolites in feed mixtures for cows. Zootekhniya 1994; 10:1-12.

22. Morinaga $F$, Satou T, Sasaki K, Yoshida S, Kiku Y, Ozawa T, Hayashi T. The effects of natural materials (Stevia liquid, staxanthin mixed feed, and zeolite powder) on the somatic cell count of holstein cows with spontaneous mastitis. Bulletin of the Fukui Experiment Station of Domestic Animal Industry. [en linea]. 2010; (access September 10, 2013) URL available: http://agris.fao.org/agris-search/ search/display .do?f= 2010\%2FJP\%2FJP1022. xml\%3BJP2010003810.

23. Katsoulos PD, Zarogiannis S, Roubies $\mathrm{N}$, Christodoulopoulos G.Effect of long-term dietary supplementation with clinoptilolite on performance and selected serum biochemical values in dairy goats. Am J Vet Res 2009; 70(3):346-52. 